\title{
CONTENT OF TOXIC AND ESSENTIAL METALS IN MEDICINAL HERBS GROWING IN POLLUTED AND UNPOLLUTED AREAS OF MACEDONIA
}

\author{
Darinka GJORGIEVA ${ }^{1}$, Tatjana KADIFKOVA-PANOVSKA², Katerina BAČEVA ${ }^{3}$, and \\ Trajče STAFILOV ${ }^{3}$
}

Faculty of Medical Sciences, "Goce Delčev” University, Štip ${ }^{1}$ Faculty of Pharmacy, "Ss. Cyril and Methodius" University2, Institute of Chemistry, Faculty of Natural Sciences and Mathematics, "Ss. Cyril and Methodius" University ${ }^{3}$, Skopje, Macedonia

Received in January 2010

Accepted in June 2010

\begin{abstract}
The aim of this study was to determine and compare $\mathrm{Ba}, \mathrm{Cr}, \mathrm{Cd}, \mathrm{Fe}, \mathrm{Sr}, \mathrm{Pb}$, and $\mathrm{Zn}$ content in medicinal herbs Urtica dioica L., Taraxacum officinale, and Matricaria recutita growing in polluted and unpolluted areas of the Republic of Macedonia. The metal content was determined using inductively coupled plasma atomic emission spectroscopy (ICP-AES). In the unpolluted area of Mt. Plačkovica the metal content in Taraxacum officinale was in the descending order: $\mathrm{Fe}>\mathrm{Sr}>\mathrm{Zn}>\mathrm{Ba}>\mathrm{Cr}$, while $\mathrm{Pb}$ and $\mathrm{Cd}$ were below the limit of detection. In the polluted area of Veles, the order was as follows: $\mathrm{Fe}>\mathrm{Zn}>\mathrm{Sr}>\mathrm{Pb}>\mathrm{Ba}>\mathrm{Cd}>\mathrm{Cr}$. Our results suggest that quality assurance and monitoring of toxic metals is needed for plants intended for human use and consumption. Medicinal plants should be picked in areas free of any contamination sources.
\end{abstract}

KEY WORDS: $B a, C d, C r, F e$, Matricaria recutita, $P b, S r$, Taraxacum officinale, Urtica dioica, $Z n$

A World Health Organization (WHO) report (1) suggests that in primary healthcare about $70 \%$ to $80 \%$ of the world population rely on unconventional medicine, mainly of herbal origin. Phytotherapy has a very long tradition and in recent years, we have witnessed increasing popularity of over-the-counter (OTC) drugs, nutraceuticals, and medicinal products of plants or other natural resources. Even though medicinal herbs are often advertised as natural and therefore harmless they can produce adverse effects too, including toxic effects, allergic reactions, and drug interactions (2). Herbs such as Aloe vera, Valeriana officinalis, and Symphytum officinale could also be hepatotoxic (3).

Moreover, they can be contaminated with pesticides, microbes, heavy metals, and toxic chemicals. Pesticides, microbial, and heavy metal contamination may be related to the environment in which herbs are grown or stored (2). Minerals essential for growth accumulate in different plant parts, but so do metals such as $\mathrm{Cd}, \mathrm{Co}$, and $\mathrm{Ag}$, which are of no known use for the plant (4).

Atmosphere, soil, harvesting, and handling play an important role in metal contamination of medicinal plants. Plants are an important link in the transfer of trace elements from soil to man (5). It is therefore important to establish the levels of some metals in common medicinal plants because they can be dangerous if elevated (6). The concentration of heavy metals in plants is one of the criteria for production of drugs. WHO has set maximum permissible levels in raw plant materials only for arsenic, cadmium, and lead $\left(1.0 \mathrm{mg} \mathrm{kg}^{-1}, 0.3 \mathrm{mg} \mathrm{kg}^{-1}\right.$, and $10 \mathrm{mg} \mathrm{kg}^{-1}$, respectively) (7). Provisional Tolerable Weekly Intake 
(PTWI) for mercury is $5 \mu \mathrm{g} \mathrm{kg}^{-1}$ body mass (b.m.), arsenic $15 \mu \mathrm{g} \mathrm{kg}^{-1}$ b.m., lead $25 \mu \mathrm{g} \mathrm{kg}^{-1}$ b.m., and cadmium $7 \mu \mathrm{g} \mathrm{kg}^{-1}$ b.m., as the major toxic elements $(8,9)$. Furthermore, the European Commission has established lead, cadmium, and mercury limits in food supplements (10) that have been in force since March 2001.

Because of the importance of mineral and trace elements in medicinal herbs, several studies have been carried out to determine their levels by using different methods (11-14). The objective of this study was to quantify and compare the content of $\mathrm{Ba}, \mathrm{Cr}, \mathrm{Cd}, \mathrm{Fe}$, $\mathrm{Sr}, \mathrm{Pb}$, and $\mathrm{Zn}$ in medicinal herbs Urtica dioica $\mathrm{L}$. (Urticaceae), Taraxacum officinale (Asteraceae), and Matricaria recutita (Asteraceae) growing in a polluted and unpolluted area of the Republic of Macedonia (Figure 1). These herbs are commonly used by local people for infusions and phytotherapeutical purposes. The selected elements are important essential or toxic metals to humans.

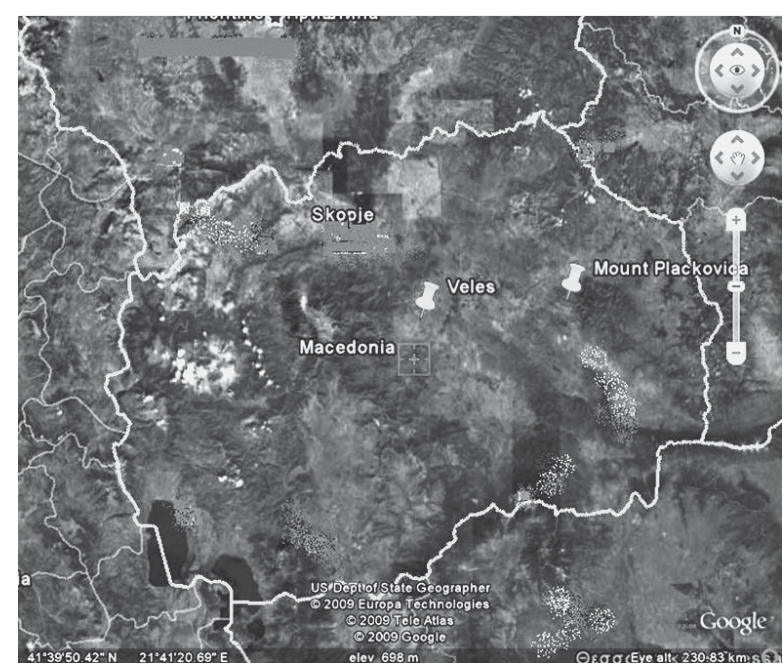

Figure 1: Sampling locations town of Veles (polluted) and Mt. Plačkovica (unpolluted) in Macedonia

\section{MATERIALS AND METHODS}

\section{Sampling areas}

All samples were collected in May 2009. Samples from the polluted area were taken $10 \mathrm{~m}$ to $100 \mathrm{~m}$ around the lead and zinc smelting plant "Zletovo" in the town of Veles (Figure 1). We selected this smelting plant because it is an important source of lead pollution in Macedonia, with estimated emission of 83 tonnes per year, according to the 1996 National Environmental Action Plan (NEAP). Several studies of heavy metal content in soil, vegetables and fruits of this area have confirmed pollution (15-17). Control samples were taken an unpolluted area on Mt. Plačkovica, about $60 \mathrm{~km}$ from Veles. The plants were identified at the Department of Pharmacognosy, Faculty of Pharmacy, Skopje, Macedonia. Plants sampled and their locations are described in Table 1.

\section{Sample collection and preparation}

We collected three plants (about $200 \mathrm{~g}$ fresh mass) of each species from each location for analysis. For T. officinale we took well developed rosette leaves of similar size; for $U$. dioica we used leaves of similar size cut with a non-metal knife and for $M$. recutita we used the flowers. All plant samples were air dried unrinsed, milled in a micro-hammer (without metal parts in it), and stored in clean paper bags.

\section{Analytical techniques}

For all standard and sample preparations we used demineralised water and high purity reagents (Tracepur ${ }^{\circledR}$, Merck, Germany). Standards of selected elements were set by dilution of stock standards, which were prepared using analytical grade salts of metals (Merck, Germany) with $\mathrm{HNO}_{3}$ and results were corrected for reagent blanks.

We weighed $0.5 \mathrm{~g}$ of each finely crushed item and placed them in polytetrafluoroethylene vessels with $5 \mathrm{~mL}$ of $69 \% \mathrm{HNO}_{3}$ Tracepur $^{\circledR}$, Merck, Germany) and $2 \mathrm{~mL}$ of $30 \% \mathrm{H}_{2} \mathrm{O}_{2}(\mathrm{~m} / \mathrm{V}$; Merck, Germany). The mixture was left at room temperature for $1 \mathrm{~h}$ and then mineralised in a microwave (MARS CEM XP 1500) in a two-step procedure at $180{ }^{\circ} \mathrm{C}$ (Table 2). The digests were filtered on filter paper (Munktell, Sweden), quantitatively transferred to $25 \mathrm{~mL}$ calibrated flasks, diluted with demineralised water and analysed for selected metals with an inductively coupled plasma atomic emission spectrometer (ICP-AES) (Varian 715-ES, Varian, USA). Instrument settings are given in Table 3. All results were calculated on a dry mass basis ( $\mathrm{mg} \mathrm{kg}^{-1} \mathrm{~d}$.m.). Samples were made in triplicate. Each data represents the mean \pm standard deviation of three samples.

\section{RESULTS AND DISCUSSION}

Figure 2 shows mean values of the investigated metals in the three plant species. In the Taraxacum leaves collected in the unpolluted area of Mt. 
Table 1 Plant organ analysed and sampling location

\begin{tabular}{|c|c|c|c|}
\hline \multirow{3}{*}{$\begin{array}{l}\text { Plant, plant organ } \\
\text { investigated }\end{array}$} & \multicolumn{3}{|c|}{$\begin{array}{l}\text { Location (unpolluted area) } \\
\text { Plackovica Mountain }\end{array}$} \\
\hline & \multicolumn{2}{|c|}{ coordinates } & \multirow{2}{*}{ Altitude above sea-level } \\
\hline & $\mathbf{N}$ & $\mathbf{E}$ & \\
\hline Urtica dioica leaves & $41^{\circ} 47^{\prime} 11.58^{\prime \prime}$ & $22^{\circ} 20^{\prime} 06.49^{\prime \prime}$ & $740 \mathrm{~m}$ \\
\hline Taraxacum officinale leaves & $41^{\circ} 47^{\prime} 11.85^{\prime \prime}$ & $22^{\circ} 20^{\prime} 08.01^{\prime \prime}$ & $745 \mathrm{~m}$ \\
\hline Matricaria recutita flowers & $41^{\circ} 48^{\prime} 13.42^{\prime \prime}$ & $22^{\circ} 17^{\prime} 10.80^{\prime \prime}$ & $382 \mathrm{~m}$ \\
\hline \multirow{3}{*}{$\begin{array}{l}\text { Plant, plant organ } \\
\text { investigated }\end{array}$} & \multicolumn{3}{|c|}{$\begin{array}{c}\text { Location (polluted area) } \\
\text { Veles area }\end{array}$} \\
\hline & \multicolumn{2}{|c|}{ coordinates } & \multirow{2}{*}{ Altitude above sea-level } \\
\hline & $\mathbf{N}$ & $\mathbf{E}$ & \\
\hline Urtica dioica leaves & $41^{\circ} 43^{\prime} 30.14^{\prime \prime}$ & $21^{\circ} 45^{\prime} 51.87^{\prime \prime}$ & $176 \mathrm{~m}$ \\
\hline Taraxacum officinale leaves & $41^{\circ} 43^{\prime} 41.20^{\prime \prime}$ & $21^{\circ} 46^{\prime} 04.23^{\prime \prime}$ & $169 \mathrm{~m}$ \\
\hline Matricaria recutita flowers & $41^{\circ} 43^{\prime} 46.25^{\prime \prime}$ & $21^{\circ} 46^{\prime} 00.75^{\prime \prime}$ & $168 \mathrm{~m}$ \\
\hline
\end{tabular}

Table 2 Procedure used for the digestion of plant samples

\begin{tabular}{lccc}
\hline Step & Temperature $/{ }^{\circ} \mathbf{C}$ & Time $/$ min & Power $/ \mathbf{W}$ \\
\hline 1 & 180 & 10 (ramp time) & 800 \\
\hline 2 & 180 & 15 (hold time) & 800 \\
\hline
\end{tabular}

Table 3 Operating conditions for ICP-AES (Varian, 715ES)

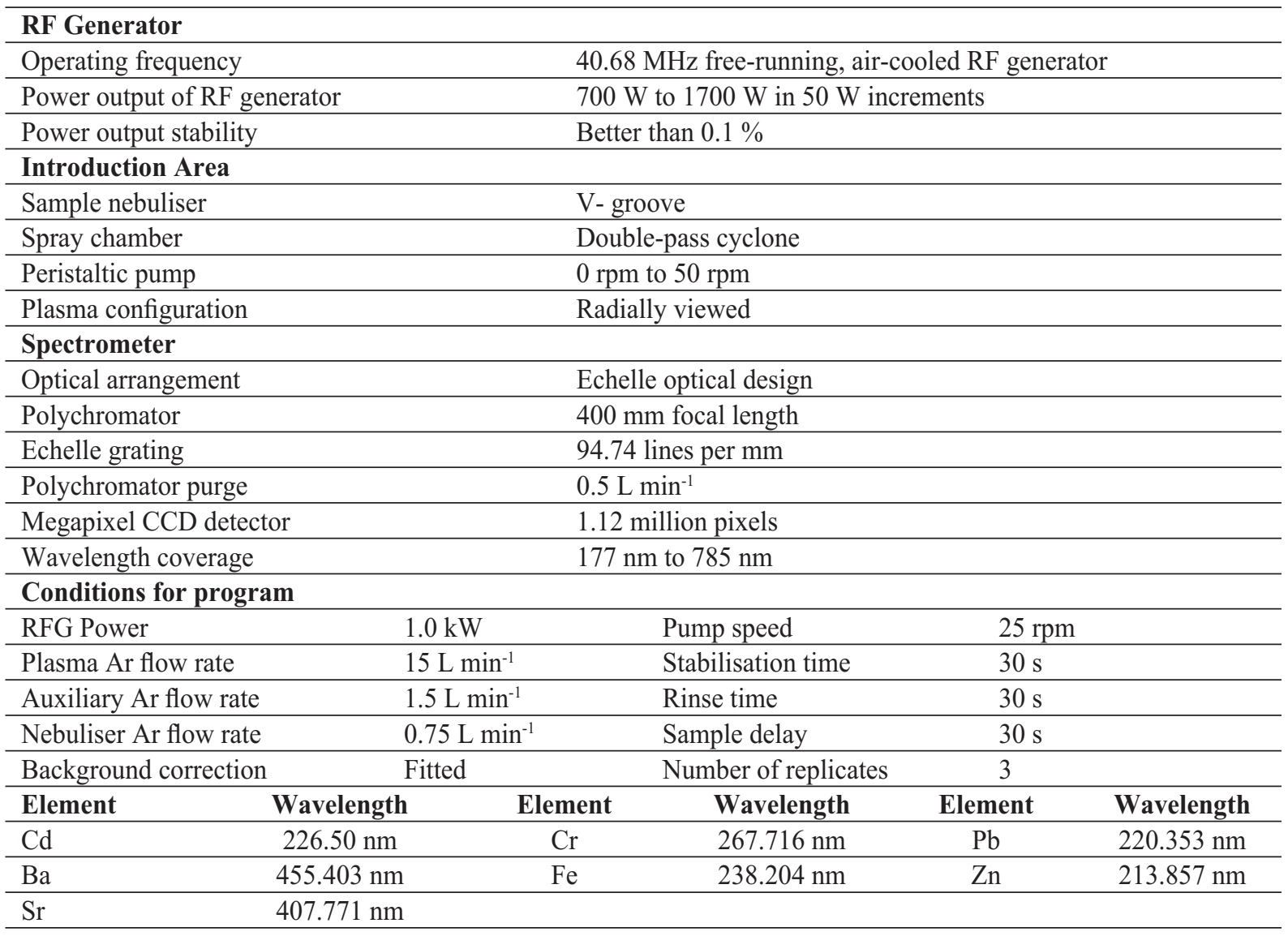

Plačkovica, the highest metal content was found for $\mathrm{Fe}$, followed by $\mathrm{Sr}, \mathrm{Zn}, \mathrm{Ba}$, and $\mathrm{Cr}$, while $\mathrm{Pb}$ and $\mathrm{Cd}$ were below the detection limit. In samples collected from the polluted area of Veles, the highest content was again that of $\mathrm{Fe}$, followed by $\mathrm{Zn}, \mathrm{Sr}, \mathrm{Pb}, \mathrm{Ba}, \mathrm{Cd}$, and $\mathrm{Cr}$.

Iron is an essential metal for plants and animals. The levels of iron were very high in $T$. officinale 


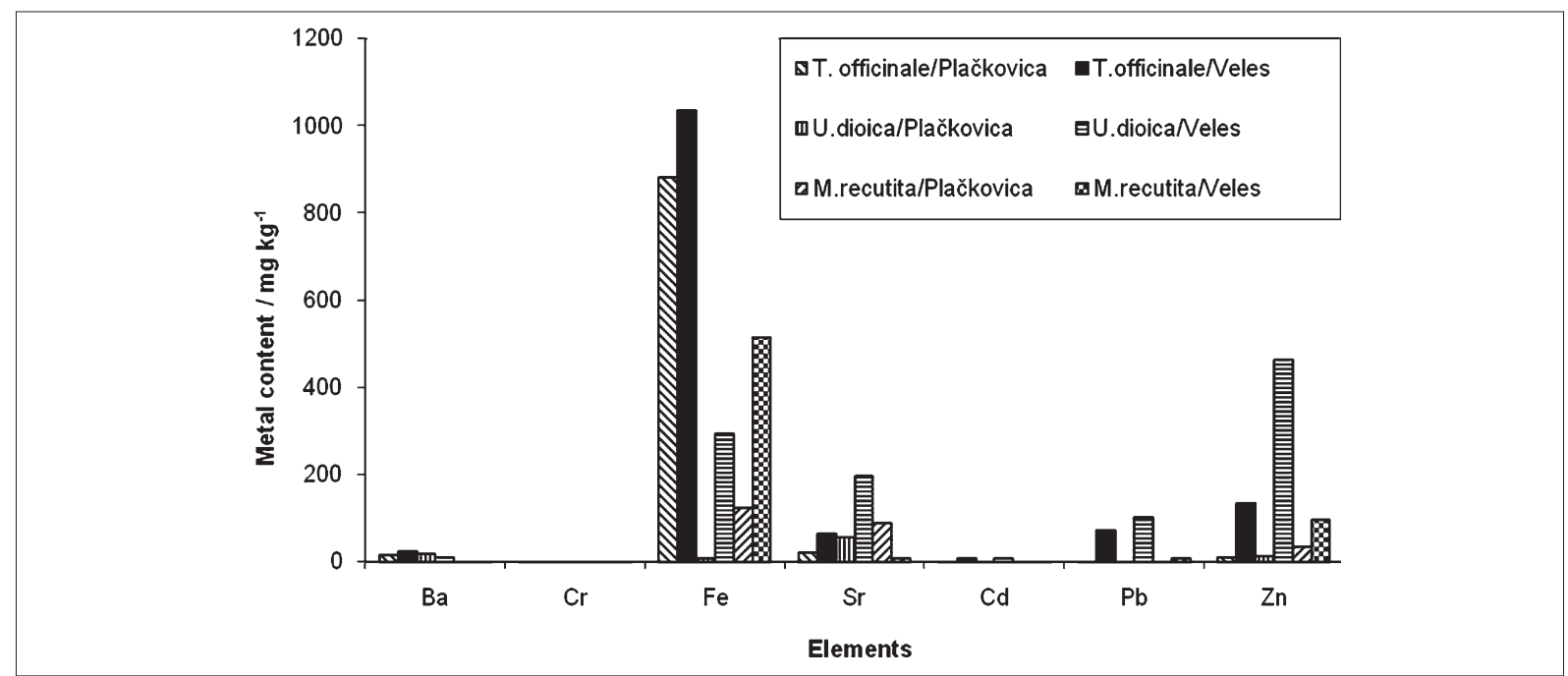

Figure 2: Content of selected metals $\left(\mathrm{mg} \mathrm{kg}^{-1}\right)$ in three medicinal plants sampled from the polluted (Veles) and unpolluted (Mt. Plačkovica) area in Macedonia

leaves $\left(881.46 \pm 0.4 \mathrm{mg} \mathrm{kg}^{-1}\right.$ for Mt. Plačkovica and $1036 \pm 4.35 \mathrm{mg} \mathrm{kg}^{-1}$ for Veles) and the lowest in $U$. dioica leaves $\left(6.72 \pm 0.2 \mathrm{mg} \mathrm{kg}^{-1}\right.$ for Mt. Plačkovica and $515 \pm 0.5 \mathrm{mg} \mathrm{kg}^{-1}$ for Veles). The highest Fe content was found in herbs growing in the polluted area. The obtained values are close to those found by Maiga et al. (18) where the highest Fe plant level was $1500 \mathrm{mg} \mathrm{kg}^{-1}$ or by Kalny et al. (19) (522士225) mg $\mathrm{kg}^{-1}$ or by Arceusz et al. (20) (307 $\left.\mathrm{mg} \mathrm{kg}^{-1}\right)$.

Strontium content in our study ranged from $8.94 \pm 0.13 \mathrm{mg} \mathrm{kg}^{-1}$ in $M$. recutita from Veles to (195.8 \pm 0.4$) \mathrm{mg} \mathrm{kg}^{-1}$ in $U$. dioica, also from Veles. Strontium is a relatively common trace element in the Earth's crust, it is very mobile and therefore readily taken up by plants. Its usual content in different food and feed plants ranges from $10 \mathrm{mg} \mathrm{kg}^{-1}$ to $1,500 \mathrm{mg} \mathrm{kg}^{-1}$ d.w. (21). Our results are at the low end of this range.

Zinc is an essential element in all organisms and plays an important role in the biosynthesis of enzymes, auxins, and proteins. It is not highly phytotoxic and the toxicity limit ( $300 \mathrm{mg} \mathrm{kg}^{-1}$ to $400 \mathrm{mg} \mathrm{kg}^{-1}$ ) depends on plant species and growth stage (21). Several authors $(22,23)$, find the leaf concentration of $100 \mathrm{mg} \mathrm{kg}^{-1}$ indicative of environmental pollution with $\mathrm{Zn}$.

All of the herbs growing near the lead and zinc smelting plant in Veles had higher $\mathrm{Zn}$ content: $(465 \pm 2.3) \mathrm{mg} \mathrm{kg}^{-1}$, (134.1 \pm 0.3$) \mathrm{mg} \mathrm{kg}^{-1}$, and $(96.58 \pm 0.3) \mathrm{mg} \mathrm{kg}^{-1}$ for $U$. dioica, T. officinale, and $M$. recutita, respectively, than control herbs growing on Mt. Plačkovica, where the highest $\mathrm{Zn}$ content was found in M. recutita flower $(35.34 \pm 0.2) \mathrm{mg} \mathrm{kg}^{-1}$, which is well below the WHO permissible level of $60 \mathrm{mg} \mathrm{kg}^{-1}$ (24). Our results are in agreement with earlier findings of high $\mathrm{Zn}$ soil contamination in Veles (17). Kalny et al. (19) found the highest Zn level (221 \pm 42$) \mathrm{mg} \mathrm{kg}^{-1}$ in Crataegus species.

A large number of plants contain small quantities of Ba (4 mg kg${ }^{-1}$ to $\left.50 \mathrm{mg} \mathrm{kg}^{-1}\right)$ (25). Larger quantities can be toxic for plants and humans, and inhibit plant growth as well. In our study, Ba content ranged from $(3.78 \pm 0.1) \mathrm{mg} \mathrm{kg}^{-1}$ (M. recutita, polluted area) to $(25.28 \pm 0.2) \mathrm{mg} \mathrm{kg}^{-1}$ (T. officinale, polluted area). Kalny et al. (19) reported Ba values from (25.0 \pm 12.3$) \mathrm{mg} \mathrm{kg}^{-1}$ to $(72.6 \pm 9.4) \mathrm{mg} \mathrm{kg}^{-1}$.

Chromium is a nonessential element to plants. At $100 \mu \mathrm{mol} \mathrm{L}{ }^{-1} \mathrm{~kg}^{-1}$ d.m., it is toxic to most of the taller plants (26), and according to Allen (22), at levels above $0.5 \mathrm{mg} \mathrm{kg}^{-1} \mathrm{Cr}$ is toxic to all plants. The highest $\mathrm{Cr}$ content in our study was $(1.88 \pm 0.05) \mathrm{mg} \mathrm{kg}^{-1}$ in the unpoluted area and $(2.59 \pm 0.2) \mathrm{mg} \mathrm{kg}^{-1}$ in the polluted area. These findings are comparable to results published earlier $(18,27)$.

According to Kabata-Pendias and Pendias (21), $\mathrm{Pb}$ in plants ranges from $0.1 \mathrm{mg} \mathrm{kg}^{-1}$ to $10 \mathrm{mg} \mathrm{kg}^{-1} \mathrm{~d}$.m. and according to Allen (22) the average content is $3 \mathrm{mg} \mathrm{kg}^{-1}$. Kloke et al. (28) propose a $\mathrm{Pb}$ toxic range of $30 \mathrm{mg} \mathrm{kg}^{-1}$ to $300 \mathrm{mg} \mathrm{kg}^{-1}$. The degree of heavy metal concentration in leaves seems to be proportional to urbanisation, industrial activity, and traffic density (29).

Some authors have also suggested that normal $\mathrm{Cd}$ levels in plants range between $0.2 \mathrm{mg} \mathrm{kg}^{-1}$ to $0.8 \mathrm{mg} \mathrm{kg}^{-1}$ and that toxic levels range between 
$5 \mathrm{mg} \mathrm{kg}^{-1}$ and $30 \mathrm{mg} \mathrm{kg}^{-1}(21,28)$. Our results (Figure 2) show a high $\mathrm{Cd}$ and $\mathrm{Pb}$ content in all medicinal herbs from the polluted area of Veles. According to the above ranges, $\mathrm{Pb}$ and $\mathrm{Cd}$ in $U$. dioica and $T$. officinale fall within the toxic range for plants. The highest level of $\mathrm{Pb}$ in $U$. dioica leaves was $(102.03 \pm 0.14) \mathrm{mg} \mathrm{kg}^{-1}$ and of $\mathrm{Cd}(7.37 \pm 0.04) \mathrm{mg} \mathrm{kg}^{-1}$. Similar are the levels of $\mathrm{Pb}$ and $\mathrm{Cd}$ in $T$. officinale $(73.92 \pm 0.5) \mathrm{mg} \mathrm{kg}^{-1}$ and $(7.24 \pm 0.2) \mathrm{mg} \mathrm{kg}^{-1}$, respectively. In contrast, $\mathrm{Pb}$ and $\mathrm{Cd}$ levels in $M$. recutita were significantly lower [(7.94 \pm 0.1$) \mathrm{mg} \mathrm{kg}^{-1}$ and $(1.57 \pm 0.1) \mathrm{mg} \mathrm{kg}^{-1}$, respectively]. This finding is similar to earlier $\mathrm{Cd}$ measurements in chamomile plants (30).

$\mathrm{Pb}$ and $\mathrm{Cd}$ levels in herbs growing in the unpolluted area were below the limit of detection for the method $\left(\mathrm{LD}<1 \mathrm{mg} \mathrm{kg}^{-1}\right.$ ) for $T$. officinale. In $U$. dioica leaves the $\mathrm{Pb}$ level was (3.86 \pm 0.1$) \mathrm{mg} \mathrm{kg}^{-1}$ while Cd remained below the detection limit and in $M$. recutita flowers the $\mathrm{Pb}$ level was $(1.48 \pm 0.05) \mathrm{mg} \mathrm{kg}^{-1}$ and $\mathrm{Cd}$ level $(0.13 \pm 0.02) \mathrm{mg} \mathrm{kg}^{-1}$. Even the highest $\mathrm{Pb}$ level is below the WHO permissible limit of $10 \mathrm{mg} \mathrm{kg}^{-1}$ for $\mathrm{Pb}$ in food (24).

The use of medicinal plants is perhaps the oldest way to treat illness (31). Due to widespread and prolonged use of medicinal herbs, their metal constituents could cause a variety of adverse effects (32). Furthermore, metals are sometimes intentionally added to Asian herbal preparations, because the traditional Indian (Ayurvedic) and Chinese medicine believes in their therapeutic properties (33). Therefore, it is not uncommon to find excessive quantities of toxic elements in such formulations. Herbal products from all over the world, such as those from Africa $(18,27$, 32), Europe $(5,14,19)$, and South America (34) have also been reported to contain high concentrations of toxic elements and pose a serious health risk.

\section{CONCLUSIONS}

Our study has demonstrated that the content of investigated metals in Macedonian medicinal plants from the unpolluted area is below or close to the WHO limits, and that their content in plants growing in the polluted area exceeds these limits. Quality assurance and monitoring of toxic metals is therefore a must for plants intended for human use and consumption. Medicinal plants should be picked in areas free of any contamination sources.

\section{REFERENCES}

1. World Health Organization (WHO). Traditional Medicine Strategy 2002-2005. Geneva: WHO; 2002.

2. Chan K. Some aspects of toxic contaminants in herbal medicines. Chemosphere 2003;52:1361-71.

3. Stickel F, Patsenker E, Schuppan D. Herbal hepatotoxicity. J Hepatol 2005;43:901-10.

4. Dushenkov V, Kumar PBAN, Motto H, Raskin I. Rhizofiltration: the use of plants to remove heavy metals from aqueous streams. Environ Sci Technol 1995;29:1239-45.

5. Lozak A, Soltyk K, Ostapezuk P, Fijalek Z. Determination of selected trace elements in herbs and their infusions. Sci Total Environ 2002;289:33-40.

6. Schumacher M, Bosque MA, Domingo JL, Corbell J. Dietary intake of lead and cadmium from foods in Tarragona Province, Spain. Bull Environ Contam Toxicol 1991;46:3208

7. World Health Organization (WHO). Quality Control Methods for Medicinal Plant Materials. Geneva: WHO; 1998.

8. World Health Organization (WHO). Evaluation of certain food additives and contaminants. Fifty-third Report of the Joint FAO/WHO Expert Committee on Food Additives. Technical Report Series 896. Geneva: WHO; 2000.

9. Food and Agriculture Organization of the United Nations, and World Health Organization. Summary of Evaluation Performed by the Joint FAO/WHO Expert Committee on Food Additives (JECFA). 64 ${ }^{\text {th }}$ meeting. 8-17 Feb 2005. Rome, Italy [displayed 15 July 2009]. Available at ftp://ftp. fao.org/es/esn/jecfa/jecfa64_summary.pdf.

10. Commission Regulation (EC) No. 466/2001 of 8 March 2001 setting maximum levels for certain contaminants in foodstuffs. Official Journal of the European Communities [displayed 13 May 2010]. Available et http://www.caobisco. com/doc uploads/legislation/466-2001EN.pdf.

11. Reimann C, Koller F, Frengstad B, Kashulina G, Niskavaara $\mathrm{H}$, Englmaier P. Comparison of the element composition in several plants species and their substrate from a 1500000 $\mathrm{km}^{2}$ area in Northern Europe. Sci Total Environ 2001;279:87112 .

12. Adamo P, Vingiani S, Castaldo Cobianchi R, Violante P. Trace element accumulation by moss and lichen exposed in bags in the city of Naples (Italy). Environ Pollut 2003;122:91103.

13. Tüzen M. Determination of heavy metals in soil, mushroom and plant samples by atomic absorption spectrometry. Microchem J 2003;74:289-97.

14. Basgel S, Erdemoğlu SB. Determination of mineral and trace elements in some medicinal herbs and their infusions consumed in Turkey. Sci Total Environ 2006;359:82-9.

15. Stafilov T, Jordanovska V. Determination of cadmium in some vegetables produced in the area near the lead and zinc smelting plant in Veles, Macedonia. Ecol Protect Environ 1997;4:35-8.

16. Barandovski L, Cekova M, Frontasyeva MV, Pavlov SS, Stafilov T, Steinnes E, Urumov V. Atmospheric deposition of trace element pollutants in Macedonia studied by the moss biomonitoring technique. Environ Monit Assess 2008;138:107-18.

17. Stafilov T, Šajn R, Pančevski Z, Boev M, Frontasyeva V, Strelkova LP. Heavy metal contamination of topsoils around a lead and zinc smelter in the Republic of Macedonia. J Hazard Mater 2010;175:896-914. 
18. Maiga A, Diallo D, Bye R, Paulsen BS. Determination of some toxic and essential metal ions in medicinal and edible plants from Mali. J Agric Food Chem 2005;53:2316-21.

19. Kalny P, Fijalek Z, Daszczuk A, Ostapczuk P. Determination of selected microelements in polish herbs and their infusions. Sci Total Environ 2007;381:99-104.

20. Arceusz A, Radecka I, Wesolowski M. Identification of diversity in elements content in medicinal plants belonging to different plant families. Food Chem 2009;120:52-8.

21. Kabata-Pendias A, Pendias H. Trace Elements in Soil and Plants. $2^{\text {nd }}$ ed. Boca Raton (FL): Lewis; 1992.

22. Allen SE. Analysis of Ecological Materials. $2^{\text {nd }}$ ed. Oxford: Blackwell Scientific Publications; 1989.

23. Dmuchowski W, Bytnerowicz A. Monitoring environmental pollution in Poland by chemical analysis of Scots Pine (Pinus sylvestris L.) needles. Environ Pollut 1995;87:84-104.

24. World Health Organization (WHO). Evaluation of certain food additives and contaminants. Forty-first Report of Joint FAO/WHO Committee on Food Additives. Technical Report Series 837. Geneva: WHO; 1993.

25. Llugany M, Poschenrieder C, Barcelo J. Assessment of Ba toxicity to bush beans. Arch Environ Contam Toxicol 2000;39:440-4.

26. Davies FT, Puryear JD, Newton RJ, Egilla JN, Grossi JAS Mycorrhizal fungi increase chromium uptake by sunflower plants: influence on tissue mineral concentration, growth, and gas exchange. J Plant Nutr 2002;25:2389-407.
27. Sheded MG, Pulford ID, Hamed AI. Presence of major and trace elements in seven medicinal plants growing in the South-Eastern Desert, Egypt. J Arid Environ 2006;66:2107.

28. Kloke A, Sauerbeck DC, Vetter H. The contamination of plants and soils with heavy metals and the transport of metals in terrestrial food chains. Nriagu JO, editor. Dahlem Workshop on Changing Metal Cycles and Human Health. Berlin: Springer Verlag; 1984. p. 113-41.

29. Celik A, Kartal A, Akdoğan A, Kaska Y. Determining the heavy metal pollution in Denizli (Turkey) by using Robinia pseudo-acacia L. Environ International 2005;31:105-112.

30. Kováčik J, Tomko J, Bačkor M, Repčák M. Matricaria chamomilla is not a hyperaccumulator, but tolerant to cadmium stress. Plant Growth Regul 2006;50:239-47.

31. Kosalec I, Cvek J, Tomić S. Contaminants of medicinal herbs and herbal products. Arh Hig Rada Toksikol 2009;60:485501.

32. Obi E, Akunyili DN, Ekpo B, Orisakwe OE. Heavy metal hazards of Nigerian herbal remedies. Sci Total Environ 2006;369:35-41.

33. Ernst E, Coon JT. Heavy metals in traditional Chinese medicines: a systematic review. Clin Pharmacol Ther 2001;70:497-504.

34. Caldas ED, Machado LL. Cadmium, mercury and lead in medicinal herbs in Brazil. Food Chem Toxicol 2004;42:599603. 


\section{Sažetak}

\section{SADRŽAJ TOKSIČNIH I ESENCIJALNIH METALA U LJEKOVITOM BILJU KOJE RASTE U} ONEČIŠĆENIM I NEONEČIŠĆENIM PODRUČJIMA U MAKEDONIJI

Cilj je ovoga istraživanja bio utvrditi i usporediti sadržaj $\mathrm{Ba}, \mathrm{Cr}, \mathrm{Cd}, \mathrm{Fe}, \mathrm{Sr}, \mathrm{Pb}$ i Zn u ljekovitom bilju Urtica dioica L., Taraxacum officinale i Matricaria recutita koje raste u onečišćenome odnosno neonečišćenome području u Republici Makedoniji. Sadržaj metala utvrdili smo s pomoću atomske emisijske spektroskopije induktivno spregnutom plazmom (engl. inductively coupled plasma atomic emission spectroscopy, krat. ICP-AES). U neonečišćenome području planine Plačkovice, sadržaj metala u Taraxacum officinale kretao se kako slijedi: $\mathrm{Fe}>\mathrm{Sr}>\mathrm{Zn}>\mathrm{Ba}>\mathrm{Cr}$, dok su $\mathrm{Pb}$ i Cd bili ispod granice detekcije. U onečišćenome području blizu talionice olova i cinka u Velesu redoslijed je bio ovakav: $\mathrm{Fe}>\mathrm{Zn}>\mathrm{Sr}>\mathrm{Pb}>\mathrm{Ba}>\mathrm{Cd}>\mathrm{Cr}$. Naši rezultati upućuju na potrebu za osiguranjem kakvoće i praćenjem razina toksičnih metala u biljaka namijenjenih ljudskoj uporabi. Ljekovito bilje valja brati u područjima bez izvora onečišćenja.

KLJUČNE RIJEČI: $B a, C d, C r, F e$, Matricaria recutita, $P b, S r$, Taraxacum officinale, Urtica dioica, $\mathrm{Zn}$

\section{CORRESPONDING AUTHOR:}

Darinka Gjorgieva

Faculty of Medical Sciences,

"Goce Delčev" University

Krste Misirkov bb, POB 201, 2000 Štip, R. Macedonia

E-mail: darinka.gorgieva@ugd.edu.mk 